\title{
Alternative Leader-Exon Usage in Mouse IGF-I mRNA Variants: Class 1 and Class 2 IGF-I mRNAs
}

\author{
Takashi Ohtsuki, Mariko Otsuki, Yousuke Murakami, Kensaku Hirata, \\ Sakae Takeuchi and Sumio Takahashi* \\ Department of Biology, Faculty of Science, Okayama University, Tsushima, \\ Okayama 700-8530, Japan
}

\begin{abstract}
The mouse IGF-I gene contains six exons, and exon 1 and exon 2 gene are considered to be leader exons. The regulatory mechanism of alternative usage of the leader exons is unclear in mice. The present study was aimed at clarifying changes in class 1 (derived from exon 1) and class 2 (derived from exon 2) IGF-I mRNA expression in mice under various conditions. Both class 1 and class 2 IGF-I mRNAs were expressed in the mouse uterus, liver and kidney, and class 1 IGF-I mRNA was the major transcript in all organs studied. In the uterus, both class 1 and class 2 IGF-I mRNA expression changed markedly during the estrous cycle, with the highest level at proestrus, but in the liver and kidney there were no significant changes in IGF-I mRNA expression during the estrous cycle. Estrogen treatment increased both class 1 and class 2 IGF-I mRNA levels in the uterus of ovariectomized mice, but class 1 mRNA expression increased more in response to estrogen treatment than class 2 mRNA expression. These findings suggest that estrogen stimulates IGF-I gene expression in uterine cells, and that a promoter involved in transcription of class 1 IGF-I mRNA is more responsive to estrogen. In conclusion, the present study revealed that two leader exons of mouse IGF-I gene are used in the uterus, liver and kidney. IGF-I mRNA levels of both classes changed during the estrous cycle in the uterus, but not in the liver or kidney. Estrogen increased IGF-I mRNA levels of both classes in the uterus.
\end{abstract}

Key words: IGF-I, leader exon, estrogen, uterus, mouse

\section{INTRODUCTION}

Insulin-like growth factor-I (IGF-I) is an integral component of multiple systems controlling somatic growth, and regulates cell-cycle progression and apoptosis (LeRoith et al., 1995; Resnicoff et al., 1995; Jung et al., 1996; Parrizas and LeRoith, 1997). IGF-I, a basic peptide of 70 amino acids is synthesized in precursor forms and processed post-translationally. The mammalian IGF-I gene consists of six exons (Rotwein et al., 1986; Shimatsu and Rotwein, 1987; Kamai et al., 1996). Exons 1 and 2 are considered to be leader exons, and encode distinct 5'-flanking untranslated regions and signal peptide sequences. Alternative usage of the two leader exons results in the generation of two types of IGF-I transcripts (class 1 and class 2). Exon 1 is spliced to exon 3 to produce class 1 IGF-I mRNA, and exon 2 is spliced to exon 3 to produce class 2 IGF-I mRNA (Lowe et al., 1987; Adamo et al., 1989, 1991; Jansen et al., 1991). Exon 3 encodes the remainder of the signal peptide and the first part of the B domain of the IGF-I peptide. Exon 4 encodes the remainder of the $\mathrm{B}, \mathrm{C}, \mathrm{A}$ and $\mathrm{D}$ domains, as well as the first part of the $E$ peptide moiety of the prohormone. Exon 5 is an alternatively spliced cassette exon of 52 base pairs

\footnotetext{
* Corresponding author. Phone: +81-86-251-7866; Fax : +81-86-251-7876; E-mail: stakaha@cc.okayama-u.ac.jp
}

(bp).

In the human IGF-I gene two alternatively used promoters are located upstream of exon 1 and exon 2, respectively. Differential usage of the promoters has been observed both in vitro and in vivo (Jansen et al., 1992). In the rat IGF-I gene two promoters are also found in the regions flanking exons 1 and 2 (Roberts et al., 1987; Hall et al., 1992). In rats class 1 IGF-I mRNA derived from exon 1 is ubiquitous and predominant in all tissues studied, but class 2 IGF-I mRNA derived from exon 2 is found principally in the liver (Shemer et al., 1992), and expression of class 2 IGF-I mRNA is more $\mathrm{GH}$-sensitive than that of class 1 transcripts (Adamo et al., 1991). These expression patterns suggest the organ-specific regulation of transcription.

In mice the presence of two promoters corresponding to the two leader exons (exons 1 and 2) has been suggested (Kamai et al., 1996); however, functional analysis of 5'upstream flanking regions of the IGF-I gene has not been undertaken. In the present study the 3'-flanking regions of exons 1 and 2 of the mouse IGF-I gene were isolated and their sequences were determined to clarify the mouse IGFI gene structure. The present study aimed to clarify the differential usage of two leader exons of the mouse IGF-I gene in the uterus. The uterus shows the next-highest level of IGF-I gene expression after the liver in rats and mice (Murphy et al., 1987). IGF-I and the type I receptor for IGFI (IGF-IR) are expressed in the mouse uterus (Kapur et al., 1992; Henemyre and Markoff, 1999; Ohtsuki et al., 2005).

doi: $10.2108 / z s j .24 .241$ 
We investigated the steady-state levels of class 1 and 2 IGF-I mRNA expression in the uterus at different ages and different stages of the estrous cycle to clarify the alternative usage of the leader exons. Furthermore, the effects of estradiol-17 $\beta$ (E2) on class 1 and class 2 IGF-I mRNA expression in the uterus of ovariectomized mice was also studied, since estrogen stimulates IGF-I mRNA expression in the uterus (Murphy et al., 1987; Kapur et al., 1992; Inoue et al., 2005; Murakami et al., 2005; Ohtsuki et al., 2005).

\section{MATERIALS AND METHODS}

\section{Animals}

Male and female ICR mice (CLEA Japan Inc., Osaka, Japan) were used in the present study. They were kept in a temperaturecontrolled animal room with free access to CE-7 commercial diet (CLEA Japan) and tap water ad libitum. Vaginal-smear sampling was conducted daily for at least two weeks. All animal care and experiments were performed in accordance with the Guidelines for Animal Experimentation of Okayama University, Japan.

\section{RNA preparation and reverse transcription}

Total RNA was extracted using the method of Chomczynski and Sacchi (1987). Total RNA $(2 \mu \mathrm{g})$ in a final volume of $20 \mu \mathrm{l}$ was subjected to reverse transcription (RT) reaction using the Superscript Preamplification System for First Strand cDNA (Gibco BRL, Gaithersburg, MD, USA) with an oligo-dT primer, according to the manufacturer's instructions.

\section{Isolation and sequence determination of the 3' flanking regions of mouse IGF-I exons 1 and 2}

Mouse class 1 and class 2 IGF-I cDNA fragments obtained from the liver were amplified by RT-PCR with a forward primer specific for each leader exon (exon 1, 5'-ATGGGGAAAATCAGCAGTC3'; exon 2, 5'-CTGCCTGTGTAAACGACCCGG-3') and a reverse primer (exon 3-4 junction, 5'-GGCTGCTTTTGTAGGCTTCAGTGG3 '). Mouse class 1- and class 2-specific primers were designed from data in previous reports on mouse exons 1 and 2 (Kamai et al., 1996) and mouse IGF-I cDNA (Bell et al., 1986). PCR was performed using Takara Taq (Takara, Otsu, Japan) and a Gene Amp PCR System 9700 thermal cycler (Applied Biosystems, Branchburg, $\mathrm{NJ})$. PCR products were electrophoresed on agarose gels. After ethidium bromide staining, class 1 (353 bp) and class 2 (333 bp) IGF-I cDNA fragments were excised from the gel and cloned into pGEM3Zf (+) (Promega, Madison, WI, USA), and sequenced with a BigDye Terminator Cycle Sequencing Kit v. 3.1 (Applied Biosystems, Foster City, CA, USA) using the appropriate PCR primers.

\section{Semi-quantitative analysis of the number of copies of class 1 and class 2 IGF-I cDNAs}

Class 1 and class 2 IGF-I cDNA fragments were amplified by PCR with the leader exon-specific primer sets for exon 1 (forward, class 1; reverse, exon 3-4 junction) and exon 2 (forward, class 2; reverse, exon 3-4 junction), and the PCR products were then electrophoresed on agarose gels. After ethidium bromide staining, class 1 (353 bp) and class 2 (333 bp) IGF-I cDNA fragments were excised from the gel and cloned into pGEM3Zf $(+)$ (Promega). EcoRI-HindIII digested fragments were electrophoresed on agarose gels, and the fragments were isolated and then quantified by measurement of the optical density at $260 \mathrm{~nm}$. The copy number of each cDNA was calculated using the following equation (Overbergh et al., 1999): $1 \mu \mathrm{g}$ of 1000 bp DNA=9.1 $\times 10^{11}$ molecules.

Serially diluted CDNA templates for class 1 -IGF-I and class 2IGF-I (class $1,1.0 \times 10^{8}, 1.0 \times 10^{7}, 1.0 \times 10^{6}, 1.0 \times 10^{5}, 1.0 \times 10^{4}$ copies per reaction; class $2,5.0 \times 10^{7}, 5.0 \times 10^{6}, 5.0 \times 10^{5}, 5.0 \times 10^{4}, 5.0 \times 10^{3}$ copies per reaction), and the RT products of uteri and liver, were amplified by $26 \mathrm{PCR}$ cycles of $20 \mathrm{sec}$ at $95^{\circ} \mathrm{C}, 30 \mathrm{sec}$ at $55^{\circ} \mathrm{C}$, and
$40 \mathrm{sec}$ at $72^{\circ} \mathrm{C}$, with an additional extension for $10 \mathrm{~min}$ at $72^{\circ} \mathrm{C}$. PCR products were electrophoresed on agarose gels. After ethidium bromide staining, the band intensity was quantified by Kodak 1D image software (Version 3.6). Glyceraldehyde-3-phosphate dehydrogenase (GAPDH) CDNA, amplified using a specific primer set (Ohtsuki et al., 2005), was used as an internal control.

\section{Semi-quantitative RT-PCR analysis of class 1 and class 2 IGF-I mRNA levels}

Class 1 and class 2 IGF-I mRNA fragments were semi-quantified by RT-PCR with the leader exon-specific primer sets described above. PCR conditions were as follows: initial activation of DNA polymerase by a $20-\mathrm{sec}$ incubation at $90^{\circ} \mathrm{C} ; 30$ cycles of $1 \mathrm{~min}$ at $95^{\circ} \mathrm{C}, 1 \mathrm{~min}$ at $55^{\circ} \mathrm{C}$, and $2 \mathrm{~min}$ at $72^{\circ} \mathrm{C}$; and an additional extension for $10 \mathrm{~min}$ at $60^{\circ} \mathrm{C}$. Ten- $\mu$ laliquots of PCR product of each reaction were electrophoresed on $2 \%$ agarose gel, stained with ethidium bromide, and quantified. Class 1 and class 2 IGF-I mRNA expression levels were normalized with H2A.X mRNA levels (Ohtsuki et al., 2005). In a preliminary study we had confirmed that the PCR products of both class 1 and class 2 IGF-I mRNA increased linearly from 22 to 26 cycles (liver), from 24 to 28 cycles (uterus) and from 26 to 28 cycles (kidney).

\section{Ovariectomy and estrogen treatment}

Adult female mice were ovariectomized at 8 weeks of age under light ether anesthesia. Seven days later, they were subcutaneously injected with estradiol-17 $\beta$ (E2, Sigma-Aldrich, St. Louis, MO, USA; E2 was dissolved in sesame oil) at doses of 25 and 250 $\mathrm{ng} / \mathrm{mouse}(0.1 \mathrm{ml})$ or with the same volume of sesame oil. At 0,3 , $6,12,24,48,72$ and $96 \mathrm{hr}$ after E2 treatment, uteri were collected for RNA extraction.

\section{Statistics}

Data are presented as the mean \pm standard error of the mean (SEM) and were analyzed by analysis of variance with the post-hoc Bonferroni/Dunn test.

\section{RESULTS}

Comparison of nucleotide sequences of the 3'-flanking regions of exons 1 and 2 of the mouse and rat IGF-I genes

The DNA sequences of mouse and rat IGF-1 exons 1 and 2 are aligned in Fig. $1 \mathrm{~A}$ and $1 \mathrm{~B}$. Exon 1 and exon 2 showed high degree of identity between the mouse and rat IGF-I genes. The 3'-flanking region of mouse IGF-I exon 1 analyzed shared $100 \%$ identity with that of rat IGF-I exon 1. The 3'-flanking region of mouse IGF-I exon 2 analyzed shared $91.4 \%$ identity with that of rat IGF-I exon 2 .

\section{Expression profiles of class 1 and class 2 IGF-I mRNA in the uterus and liver}

Using a known number of copies of class 1 and class 2 IGF-I cDNA as templates in PCR, class 1 (derived from exon 1) and class 2 (derived from exon 2) IGF-I mRNA levels were analyzed in adult female mice. The PCR products of each class of IGF-I cDNA increased in accordance with the increase of template cDNAs under the PCR conditions used (Fig. 2A). Class 1 and class 2 IGF-I mRNAs were detected in the uterus (U) and liver (L) by RT-PCR (Fig. 2B). Both class 1 and class 2 IGF-I mRNA levels were higher in the liver than in the uterus. The amount of class 1 PCR products generated from the uterine and liver samples was more than the amount of PCR products generated from the class 1 templates $\left(1.0 \times 10^{6}\right.$ copies $)$, and the amount of class $2 \mathrm{PCR}$ 
A

\begin{tabular}{|c|c|}
\hline mouse & ATGGGGAAAATCAGCAGTCTTC \\
\hline rat & 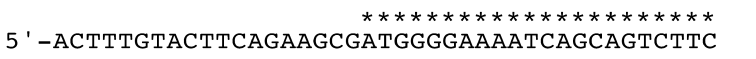 \\
\hline mouse & СААСТСААТTАТTTAАGАTСTGССТСTGTGACTTCTTGAAG-3 \\
\hline rat & $\begin{array}{l}* * * * * * * * * * * * * * * * * * * * * * * * * * * * * * * * * * * * * * * * * \\
\text { CAACTCAATTATTTAAGATCTGCCTCTGTGACTTCTTGAAG-3 }\end{array}$ \\
\hline
\end{tabular}

B

\section{exon 2}

\begin{tabular}{|c|c|}
\hline mouse & $\underset{* \star *}{\mathrm{CTG}}$ \\
\hline rat & 5 ' -CTTTGTTTTCACTTCGGCCTCATAATACCCACTCTGACCT \\
\hline louse & СTGTGTAAACGACCC-GGACCTACCAAAATGACCGCACCTG \\
\hline & $\begin{array}{l}* * * * * * * * * * * * * * * \quad * * * * \quad * * * * * * * * * * * \quad * * * * * * * \\
\text { CTGTGTAAACGACCCGGGACGTACCAAAATGAGCGCACCTC }\end{array}$ \\
\hline nouse & $\begin{array}{l}\mathrm{CA}-3^{\prime} \\
* * \\
\mathrm{CA}-3^{\prime}\end{array}$ \\
\hline
\end{tabular}

Fig. 1. DNA sequences of mouse and rat IGF-1 exon 1 (A) and exon 2 (B). Identical residues between the mouse and rat sequences are indicated by asterisks; deletions are indicated by a dash. Exons 1 and 2 of the mouse IGF-I gene show a high degree of identity with those of the rat IGF-I gene.

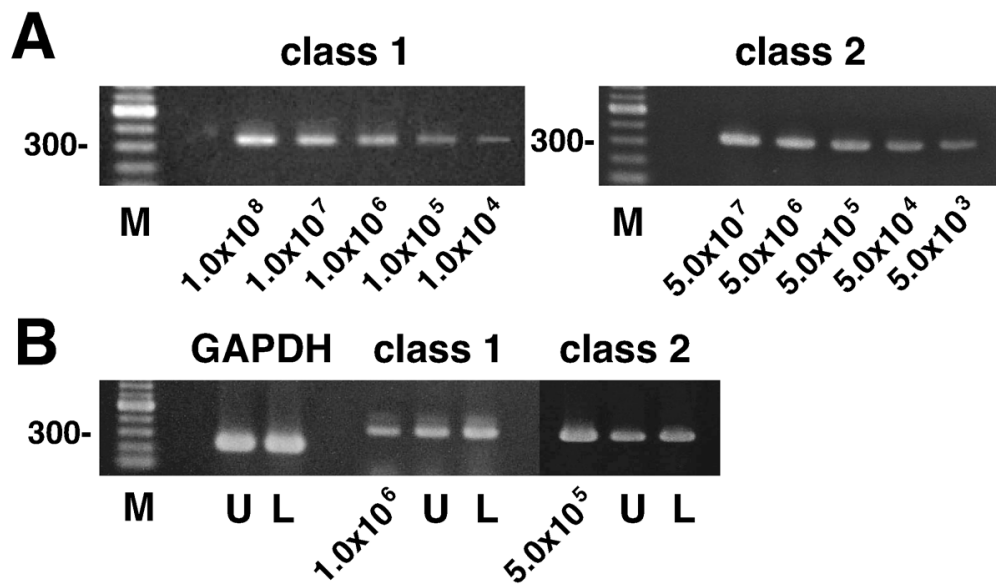

Fig. 2. RT-PCR analysis of IGF-I mRNA variant expression in the mouse uterus (U) and liver (L) using exon 1- and exon 2-specific primer pairs (see Materials and Methods). (A) PCR amplification of serially diluted class 1 and class 2 IGF-I cDNA. Serially diluted cDNA templates for class $1\left(1.0 \times 10^{8}, 1.0 \times 10^{7}, 1.0 \times 10^{6}, 1.0 \times 10^{5}, 1.0 \times 10^{4}\right.$ copies per reaction) and class $2\left(5.0 \times 10^{7}, 5.0 \times 10^{6}, 5.0 \times 10^{5}, 5.0 \times 10^{4}, 5.0 \times 10^{3} \mathrm{copies}\right.$ per reaction) IGF-I were amplified by 26 PCR cycles (see Materials and Methods). (B) Comparison of class 1 and class 2 IGF-I mRNA expression in the uterus $(\mathrm{U})$ and liver $(\mathrm{L})$ by RT-PCR. Samples from the uterus and liver and cDNA samples (class $1,1.0 \times 10^{6}$ copies; class $2,5.0 \times 10^{5}$ copies) were amplified by PCR under the same conditions as for (A). GAPDH cDNA was used as an internal control. A 100-bp ladder was used as a molecular size marker (M). The number to the left depicts the size of products (bp).

products generated from the uterine and liver samples was less than the PCR products generated from the class 2 templates $\left(5.0 \times 10^{5}\right.$ copies). The numbers of copies of class 1 and class 2 IGF-I cDNAs were determined: in the uterus, class 1 had $1.8 \times 10^{6}$ copies and class 2 had $3.2 \times 10^{5}$ copies; in the liver, class 1 had $3.6 \times 10^{6}$ copies and class 2 had $3.8 \times 10^{5}$ copies.

\section{Changes in class 1 and class 2 IGF-I mRNA levels during the estrous cycle}

To determine changes in class 1 and class 2 IGF-I expression during the estrous cycle in the uterus, liver and kidney, class 1 and class 2 IGF-I mRNA levels were measured in 60-day-old female mice by RT-PCR analysis (Fig. 3). Class 1 and class 2 IGF-I mRNA levels on the first day of diestrus (D1) were defined as 1 . In the uterus, class 1 and class 2 IGF-I mRNA levels changed markedly during the estrous cycle. The highest levels of both types of IGF-I mRNA were detected at proestrus. No significant changes in class 1 and class 2 IGF-I mRNA levels were detected in the liver and kidney during the estrous cycle. 


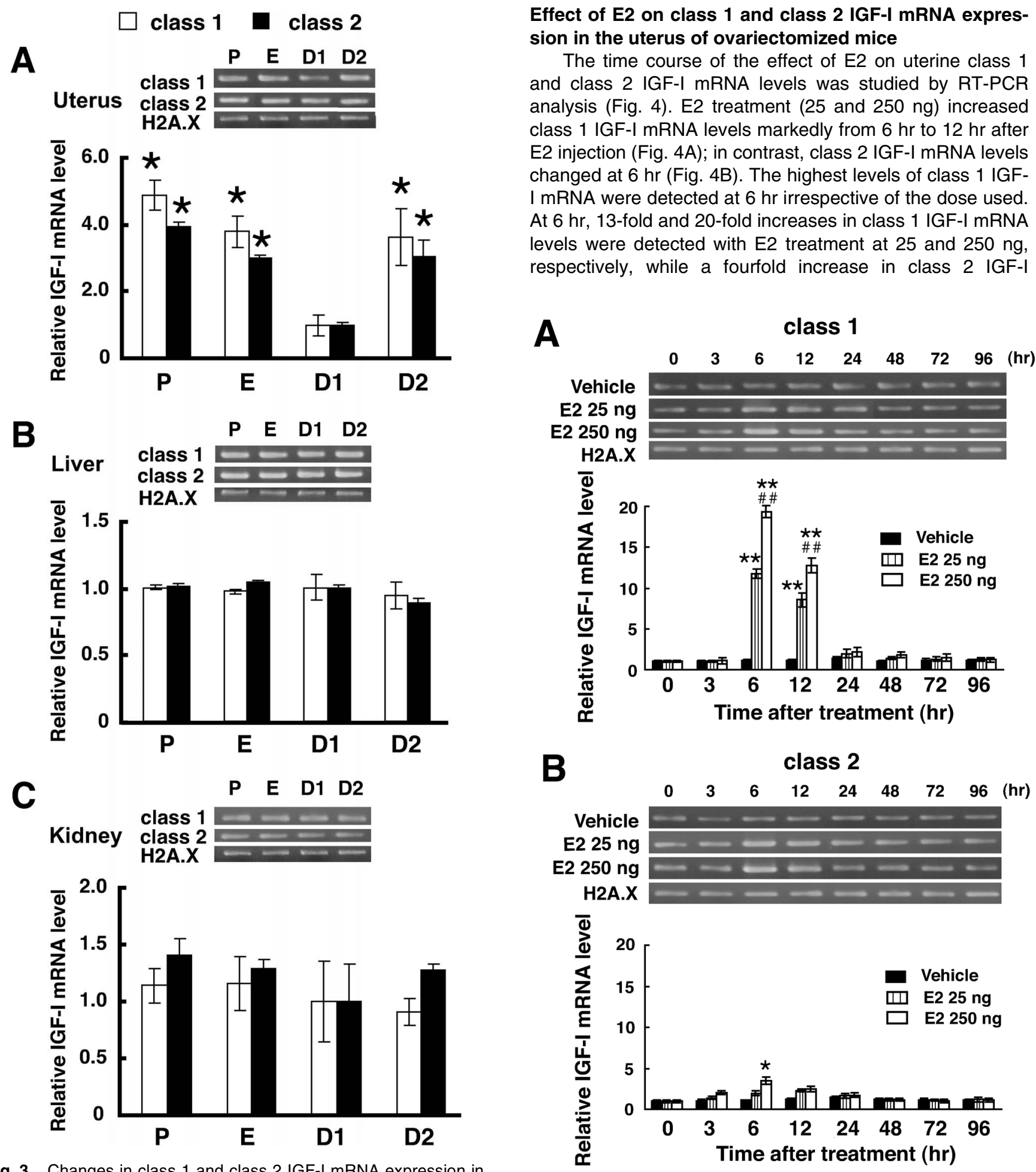

Fig. 3. Changes in class 1 and class 2 IGF-I mRNA expression in the uterus (A), liver (B), and kidney (C) during the estrous cycle. RNA samples were collected at proestrus $(P)$, estrus $(E)$, the first day of diestrus (D1), and the second day of diestrus (D2), and class 1 and class 2 IGF-I mRNA levels were determined by RT-PCR analysis, as described in Materials and Methods. Class 1 IGF-I mRNA levels are expressed by open bars, and class 2 by closed bars. Each mRNA level was normalized relative to the H2A.X mRNA level. The mRNA levels at D1 were defined as 1. Data are expressed as the mean \pm SEM $(n=5) .{ }^{*} P<0.05$, significantly different from the level at D1.

Fig. 4. Effect of E2 on class 1 (A) and class 2 (B) IGF-I mRNA expression in the uteri of ovariectomized mice. Ovariectomized mice were given a single injection of E2 ( 25 or $250 \mathrm{ng} / \mathrm{mouse}$ ) or the vehicle, which was sesame oil. Class 1 and class 2 IGF-I mRNA levels were determined by RT-PCR analysis, as described in Materials and Methods. IGF-I mRNA levels were normalized relative to the H2A.X mRNA level. The mRNA level at $0 \mathrm{hr}$ was defined as 1 . Data are expressed as the mean $\pm \operatorname{SEM}(n=3)$. ${ }^{*} P<0.05$, ${ }^{*} P<0.01$, significantly different from the vehicle-treated control; \# $P<0.05$, \#\# $\mathrm{P}<0.01$, significantly different from the level at $25 \mathrm{ng}$ E2-treated. 
mRNA levels was detected with E2 treatment at $250 \mathrm{ng}$.

\section{DISCUSSION}

Mouse IGF-I mRNAs are classified based on the usage of leader exons 1 and 2. Class 1 IGF-I mRNA is transcribed from exon 1, and class 2 from exon 2. Expression of the two leader exons of the mouse IGF-I gene was detected in the uterus, liver and kidney, as reported for human and rat IGFI genes (Lowe et al., 1987; Adamo et al., 1989; Shemer et al., 1992). We semi-quantitatively analyzed IGF-I mRNA expression and found that class 1 IGF-I mRNA was the major transcript type and showed higher expression than class 2; this is in agreement with previous reports (Lowe et al., 1987; Adamo et al., 1989, 1991). The presence of multiple leader exons and differences in IGF-I mRNA levels transcribed suggest the presence of distinct promoters controlling IGF-I gene transcription, which have already been reported for human and rat IGF-I genes (Roberts et al., 1987; Jansen et al., 1992; Wang et al., 1997). The physiological significance of the presence of multiple leader exons, and probably multiple promoters, resulting in the production of multiple types of transcripts of the IGF-I gene is unclear. However, the presence of multiple promoters for IGF-I gene transcription appears to be favorable for the organ-specific and fine control of IGF-I synthesis under various conditions, since IGF-I proteins are expressed in various cell types and have unique roles in the cells expressing them.

Two promoters of the mouse IGF-I gene are thought to be located in the 5'- flanking regions proximal to exons 1 and 2, but these two putative promoters have not yet been characterized (Kamai et al., 1996). Usage of the leader exons was analyzed in mouse uterus, liver and kidney during the estrous cycle. In the uterus, class 1 and class 2 IGFI mRNA expression changed markedly during the estrous cycle, with the highest levels at proestrus. There was a fivefold increase in class 1 expression and a fourfold increase in class 2 IGF-I mRNA expression in proestrus compared to the first day of diestrus, while in the liver and kidney there were no significant changes in class 1 or class 2 IGF-I mRNA expression during the estrous cycle.

Estrogen is well known to stimulate IGF-I gene expression in the uterus (Murphy et al., 1987; Kapur et al., 1992; Inoue et al., 2005; Murakami et al., 2005), and we also showed the stimulatory role of estrogen in the expression of both types of IGF-I mRNAs in the mouse uterus. These findings indicate that the regulation of uterine class 1 and class 2 IGF-I mRNA expression is estrous cycle-dependent, and it is highly probable that the main regulator is estrogen, since blood estrogen levels are high during proestrus (Smith et al., 1975). In contrast, we did not detect changes in IGFI mRNA levels in the liver or kidney during the estrous cycle. In addition, hepatic IGF-I expression is not stimulated by estrogen treatment (Murphy and Friesen, 1988). The difference in patterns of IGF-I mRNA expression during the estrous cycle between the uterus and the other organs is not due to differences in estrogen receptor expression, since estrogen receptor mRNA was detected in the uterus, liver and kidney by RT-PCR in mice (Ohtsuki et al., 2005; Manabe et al., unpublished observation). The organ-specific regulatory mechanism of IGF-I gene expression, particularly under estrogen stimulation, needs to be studied.
Estrogen treatment increased both class 1 and class 2 IGF-I mRNA levels in the uterus of ovariectomized mice, which is in agreement with previous studies carried out in the rat uterus (Carlsson and Billig, 1991; Klotz et al., 2000), but class 1 IGF-I mRNA expression increased more in response to estrogen treatment than class 2 expression. These findings indicate that estrogen activates two putative promoters of the IGF-I gene in uterine cells, and that a promoter involved in transcription of class 1 IGF-I mRNA is more responsive to estrogen. However, during the estrous cycle, both class 1 and class 2 IGF-I mRNA levels in the uterus changed in a similar manner. IGF-I gene transcription is regulated by multiple factors, and among them progesterone is one of the main regulators and enhances estrogeninduced IGF-I mRNA expression (Kapur et al., 1992). Changes in IGF-I mRNA levels in the uterus during the estrous cycle may be regulated by not only estrogen, but also progesterone. It is highly probable that combined effects of estrogen and progesterone enhance the promoter activity involved in class 2 IGF-I mRNA expression in the uterus.

In chickens, the IGF-I gene is stimulated by estrogen through the AP-1 motif located in the promoter region (Umayahara et al., 1994). In rats, CCAAT enhancer-binding protein $\delta(\mathrm{C} / \mathrm{EBP} \delta)$ is a critical regulator of IGF-I gene transcription (Umayahara et al., 1999), and estrogen decreases IGF-I gene expression in osteoblasts through the CAMP pathway with C/EBPS (Chang et al., 2005). However, the mechanism of estrogen-induced IGF-I gene expression in the uterus remains unclear, and further study concerning the regulatory mechanism of uterine IGF-I gene expression is needed.

IGF-I is expressed in the endometrial luminal and glandular epithelia, stroma and myometrium in rats and mice (Murphy et al., 1987; Ghahary et al., 1990; Kapur et al., 1992). Enhanced IGF-I mRNA expression of both classes in the uterus at proestrus and estrus leads to the production of IGF-I protein. IGF-I stimulates DNA synthesis and the proliferation of uterine epithelial cells in rats and mice (Beck and Garner, 1992; Shiraga et al., 1997). Proliferation of uterine epithelial cells induced by estrogen is mediated by polypeptide growth factors synthesized in uterine tissues (Cooke et al., 1997). These findings suggest that IGF-I is a candidate as an estrogen-induced growth factor that regulates the proliferation of endometrial epithelial cells. Adesanya et al. (1999) demonstrated that IGF-I is involved in the G2 progression of mouse uterine cells under estrogen stimulation, although IGF-I is generally considered to act in the G1 phase as a G1-progression factor (Pestell et al., 1999).

We recently found alternative splicing of IGF-I mRNA in mice, generating two variants of IGF-I mRNA, IGF-IA and IGF-IB (Ohtsuki et al., 2005). Both IGF-IA and IGF-IB mRNAs are generated from each of class 1 and class 2 IGFI mRNA, resulting in the production of four variants of IGF-I mRNAs. Both IGF-IA and IGF-IB mRNA levels in ovariectomized mouse uteri were elevated by E2 treatment, which is in agreement with a previous rat uterus study (Klotz et al., 2000). The relative increase in class 1 IGF-I mRNA levels with estrogen was higher than that in class 2 levels. Therefore, estrogen may stimulate the alternative usage and splicing that generates class 1 IGF-I mRNA variants. Interest- 
ingly, an exonic splicing enhancer is located in human alternative exon 5 of the IGF-I gene, and serine-arginine protein splicing factor-2/alternative splicing factor promotes the splicing of human IGF-I mRNA (Smith et al., 2002). If a similar system operates in the mouse uterus, estrogen may be involved in the activation of the alternative splicing-factor system.

In conclusion, the present study revealed that two leader exons of mouse IGF-I gene operate in the uterus, liver and kidney, and that there are probably two promoters for IGF-I gene expression. Estrous cycle-dependent IGF-I gene expression was found in the uterus alone. Estrogen increased uterine IGF-I mRNA levels of both classes. The usage of the leader exons of the mouse IGF-I gene was controlled in an organ-specific and hormone (estrogen)dependent manner.

\section{ACKNOWLEDGMENTS}

This study was supported in part by a Grant-in-Aid for Scientific Research from the Japan Society for the Promotion of Science to S.T.

\section{REFERENCES}

Adamo M, Lowe WLJ, LeRoith D, Roberts CTJ (1989) Insulin-like growth factor I messenger ribonucleic acids with alternative 5'untranslated regions are differentially expressed during development of the rat. Endocrinology 124: 2737-2744

Adamo ML, Ben-Hur H, Roberts CTJ, LeRoith D (1991) Regulation of start site usage in the leader exons of the rat insulin-like growth factor-I gene by development, fasting, and diabetes. Mol Endocrinol 5: 1677-1686

Adesanya OO, Zhou J, Samathanam C, Powell-Braxton L, Bondy CA (1999) Insulin-like growth factor 1 is required for G2 progression in the estradiol-induced mitotic cycle. Proc Natl Acad Sci USA 96: 3287-3291

Beck CA, Garner CW (1992) Stimulation of DNA synthesis in rat uterine cells by growth factors and uterine extracts. Mol Cell Endocrinol 84: 109-118

Bell GI, Stempien MM, Fong NM, Rall LB (1986) Sequences of liver cDNAs encoding two different mouse insulin-like growth factor I precursors. Nucleic Acids Res 14: 7873-7882

Carlsson B, Billig H (1991) Insulin-like growth factor-I gene expression during development and estrous cycle in the rat uterus. Mol Cell Endocrinol 77: 175-180

Chang W, Parra M, Centrella M, McCarthy TL (2005) Interactions between CCAAT enhancer binding protein $\delta$ and estrogen receptor $\alpha$ control insulin-like growth factor I (igf1) and estrogen receptor-dependent gene expression in osteoblasts. Gene 345: 225-235

Chomczynski P, Sacchi N (1987) Single-step method of RNA isolation by acid guanidinium thiocyanate-phenol-chloroform extraction. Anal Biochem 162: 156-159

Cooke PS, Buchanan DL, Young P, Setiawan Y, Brody J, Korach KS, Taylor J, Lubahn DB, Cunha GR (1997) Stromal estrogen receptors mediate mitogenic effects of estradiol on uterine epithelium. Proc Natl Acad Sci USA 94: 6535-6540

Ghahary A, Chakrabarti S, Murphy LJ (1990) Localization of the sites of synthesis and action of insulin-like growth factor-I in the rat uterus. Mol Endocrinol 4: 191-195

Hall LJ, Kajimoto Y, Bichell D, Kim SW, James PL, Counts D, Nixon LJ, Tobin G, Rotwein P (1992) Functional analysis of the rat insulin-like growth factor I gene and identification of an IGF-I gene promoter. DNA Cell Biol 11: 301-313

Henemyre C, Markoff E (1999) Expression of insulin-like growth factor binding protein-4, insulin-like growth factor-I receptor, and insulin-like growth factor-I in the mouse uterus throughout the estrous cycle. Mol Reprod Dev 52: 350-359

Inoue A, Takeuchi S, Takahashi S (2005) Insulin-like growth factor-I stimulated DNA replication in mouse endometrial stromal cells. J Reprod Dev 51: 305-313

Jansen E, Steenbergh PH, LeRoith D, Roberts CTJ, Sussenbach JS (1991) Identification of multiple transcription start sites in the human insulin-like growth factor-I gene. Mol Cell Endocrinol 78: $115-125$

Jansen E, Steenbergh PH, van Schaik FM, Sussenbach JS (1992) The human IGF-I gene contains two cell type-specifically regulated promoters. Biochem Biophys Res Commun 187: 12191226

Jung Y, Miura M, Yuan J (1996) Suppression of interleukin-1 $\beta$ converting enzyme-mediated cell death by insulin-like growth factor. J Biol Chem 271: 5112-5117

Kamai Y, Mikawa S, Endo K, Sakai H, Komano T (1996) Regulation of insulin-like growth factor-I expression in mouse preadipocyte Ob1771 Cells. J Biol Chem 271: 9883-9886

Kapur S, Tamada H, Dey SK, Andrews GK (1992) Expression of insulin-like growth factor-I (IGF-I) and its receptor in the periimplantation mouse uterus, and cell-specific regulation of IGF-I gene expression by estradiol and progesterone. Biol Reprod 46: 208-219

Klotz DM, Hewitt SC, Korach KS, Diaugustine RP (2000) Activation of a uterine insulin-like growth factor I signaling pathway by clinical and environmental estrogens: requirement of estrogen receptor- $\alpha$. Endocrinology 141: 3430-3439

LeRoith D, Werner H, Beitner-Johnson D, Roberts CT Jr (1995) Molecular and cellular aspects of the insulin-like growth factor I receptors. Endocr Rev 16: 143-163

Lowe WL Jr, Roberts CT Jr, Lasky SR, LeRoith D (1987) Differential expression of alternative 5' untranslated regions in mRNAs encoding rat insulin-like growth factor I. Proc Natl Acad Sci USA 84: 8946-8950

Murakami Y, Otsuki M, Kusumoto K, Takeuchi S, Takahashi S (2005) Estrogen inhibits interleukin-18 mRNA expression in the mouse uterus. J Reprod Dev 51: 639-647

Murphy LJ, Friesen HG (1988) Differential effects of estrogen and growth hormone on uterine and hepatic insulin-like growth factor I gene expression in the ovariectomized hypophysectomized rat. Endocrinology 122: 325-332

Murphy LJ, Murphy LC, Friesen HG (1987) Estrogen induces insulin-like growth factor-I expression in the rat uterus. Mol Endocrinol 1: 445-450

Ohtsuki T, Otsuki M, Murakami Y, Maekawa T, Yamamoto T, Akasaka K, Takeuchi S, Takahashi S (2005) Organ-specific and age-dependent expression of insulin-like growth factor-I (IGF-I) mRNA variants: IGF-IA and IB mRNAs in the mouse. Zool Sci 22: 1011-1021

Overbergh L, Valckx D, Waer M, Mathieu C (1999) Quantification of murine cytokine mRNAs using real time quantitative reverse transcriptase PCR. Cytokine 11: 305-312

Parrizas M, LeRoith D (1997) Insulin-like growth factor-1 inhibition of apoptosis is associated with increased expression of the bcl-xL gene product. Endocrinology 138: 1355-1358

Pestell RG, Albanese C, Reutens AT, Segall JE, Lee RJ, Arnold A (1999) The cyclins and cyclin-dependent kinase inhibitors in hormonal regulation of proliferation and differentiation. Endocr Rev 20: 501-534

Resnicoff M, Abraham D, Yutanawiboonchai W, Rotman HL, Kajstura J, Rubin R, Zoltick P, Baserga R (1995) The insulin-like growth factor I receptor protects tumor cells from apoptosis in vivo. Cancer Res 55: 2463-2469

Roberts CT Jr, Lasky SR, Lowe WL Jr, LeRoith D (1987) Rat IGF-I cDNA's contain multiple 5'-untranslated regions. Biochem Biophys Res Commun 146: 1154-1159 
Rotwein P, Pollock KM, Didier DK, Krivi GG (1986) Organization and sequence of the human insulin-like growth factor I gene. Alternative RNA processing produces two insulin-like growth factor I precursor peptides. J Biol Chem 261: 4828-4832

Shemer J, Adamo ML, Roberts CTJ, LeRoith D (1992) Tissue-specific transcription start site usage in the leader exons of the rat insulin-like growth factor-I gene: evidence for differential regulation in the developing kidney. Endocrinology 131: 2793-2799

Shimatsu A, Rotwein P (1987) Mosaic evolution of the insulin-like growth factors. Organization, sequence, and expression of the rat insulin-like growth factor I gene. J Biol Chem 262: 78947900

Shiraga M, Takahashi S, Miyake T, Takeuchi S, Fukamachi H (1997) Insulin-like growth factor-I stimulates proliferation of mouse uterine epithelial cells in primary culture. Proc Soc Exp Biol Med 215: 412-417

Smith MS, Freeman ME, Neill JD (1975) The control of progesterone secretion during the estrous cycle and early pseudopregnancy in the rat: prolactin, gonadotropin and steroid levels associated with rescue of the corpus luteum of pseudopregnancy. Endocrinology 96: 219-226
Smith PJ, Spurrell EL, Coakley J, Hinds CJ, Ross RJ, Krainer AR, Chew SL (2002) An exonic splicing enhancer in human IGF-I pre-mRNA mediates recognition of alternative exon 5 by the serine-arginine protein splicing factor-2/alternative splicing factor. Endocrinology 143: 146-154

Umayahara Y, Billiard J, Ji C, Centrella M, McCarthy TL, Rotwein P (1999) CCAAT/enhancer-binding protein $\delta$ is a critical regulator of insulin-like growth factor-I gene transcription in osteoblasts. $J$ Biol Chem 274: 10609-10617

Umayahara $\mathrm{Y}$, Kawamori R, Watada H, Imano E, Iwama N, Morishima T, Yamasaki Y, Kajimoto Y, Kamada T (1994) Estrogen regulation of the insulin-like growth factor I gene transcription involves an AP-1 enhancer. J Biol Chem 269: 1643316442

Wang X, Yang Y, Adamo ML (1997) Characterization of the rat insulin-like growth factor I gene promoters and identification of a minimal exon 2 promoter. Endocrinology 138: 1528-1536

(Received August 31, 2006 / Accepted October 13, 2006) 